\title{
Evaluating tourism potentials for site development tourism along River Ethiope, Abraka, Nigeria
}

\author{
O. D. Awaritefe (Professor) ${ }^{1}, \&$ D. O. Ejemeyovwi (Associate Professor) ${ }^{2 *}$ \\ Department of Geography and Regional Planning, Delta State University, Abraka, Delta State, \\ Nigeria $^{1,2}$ \\ drdannygrp@gmail.com
}

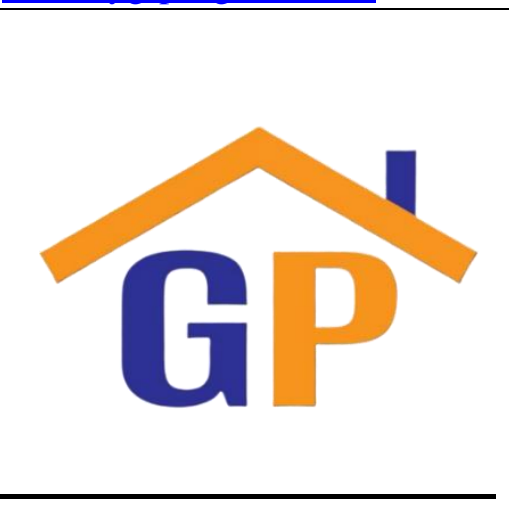

Article History

Received on 13 June 2020

$1^{\text {st }}$ Revision on 5 September 2020

$2^{\text {nd }}$ Revision on 19 September 2020

3rd Revision on 9 November 2020

Abstract

Purpose: The empirical research study evaluated environmental potentials of site locations for Tourism development along River Ethiope, Abraka Delta State, Nigeria, Four(4)sites' 40 environmental features were considered important in the tourism sites evaluation. The primary data sources used include oral interview and administration of questionnaires.

Research methodology: These are physical, biological and human components of tourism destinations, evaluated for each of the 4 sites, and compared. Each of the 40 factors was measured using appropriate instruments like measuring tape and floater (for velocity). Students $t$ test was undertaken to compare the evaluations of the two groups of professional and non-professional assessors. With a calculated value of 0.143 , and table value of 0.283 , with df2:3 at 0.05 level, the difference in site ranking between the first and second evaluation was not considered significant. High confidence or reliability can therefore be placed on the tourism site evaluation results obtained at the 0.05 significance level. The use of nominal or interval scales was to estimate variables, which were not subject to direct measurements in interval scale. Three groups of sites emerged from the preliminary survey of those selected: Natural or undeveloped sites, relate.

Results: Result obtained showed that undeveloped and natural sites emerged most highly rated in environmental potentials for tourism site development compared to underdeveloped or highly developed sites.

Limitation: The area lies within tropical equatorial rain forest vegetation which is an impenetrable ticket of under growth with trees and climbers. Moreover, dangerous reptiles especially (snakes and crocodile) as well as insect (Mosquitos and tsetse fly) are present and harmful to man in the environment.

Contribution: The study concludes and suggests natural sites be accord priority in tourism site development along River Ethiope and invariably other related natural area worldwide for maximum patronage implications based on advocated research methodology.

Keywords: Tourism, Site, Evaluation, Development, River Ethiope, Abraka

How to cite: Awaritefe, O. D., \& Ejemeyovwi, D. O. (2019). Evaluating tourism potentials for site development tourism along river Ethiope Abraka, Nigeria. Journal of Sustainable Tourism and Entrepreneurship, 1(2), 151-164. 


\section{Introduction}

The Federal and several State governments in Nigeria presently indicate keen interest to develop tourism industry. This is evidenced in increased funds allocated to the tourism sector in their budget allocations and program formulations. For instance, the Delta State government allocated over N420 million to tourism development in 2020 fiscal year budget, The amount, according to the state government, shall be used to develop tourism beaches along River Niger at Asaba, and River Ethiope at Abraka.

The context of tourist destination site describes a place to be marketed by various stake holders of tourism. As a result, the term marketing places as appeared in Kotler et al., (2010) work indicated that a product of tourism may also be a place. Kotler and Keller, (2009) and Kotler et al., (2010) described it as an entity that can be marketed which is made up of ten items ranging from items, services, experiences, people, places, properties, organizations, information to ideas. The entity of the product of tourism constitutes an accumulation of the experiences of tourists starting from when they landed at the airport or stop at train and Motor Park. The elemental view of tourist destination is described in many ways by researchers such as Mill, (2009, UNWTO (2012) and Cooper et al. (1993). According to Mill, (2009) Tourist Destination (TD) is frequently referred to as Destination Mix (DM) which is defined with the following element: attraction, facilities, infrastructure, transportation and hospitality (AFITH). Furthermore, Copper et al. (1993) stated that the tourist destination element are made up of four items referred to as 4A such as: (a) Access (b) Amenities (c) Attraction and (d) Ancillary

Moreover, the UNWTO, (2012) stated six elements of tourist destination: amenity, access, attractions, human resources and price. Hsu et al., (2008) with Mill, (2009) described a tourist destination with four variables. These main components of a tourist destination are made up of facilities, infrastructure, attraction and tourist destination that indicates that a tourist destination is a combination of various elements which gives different experiences with the objectives of satisfying the tourists' last experience.

Ritchie and Crouch, (2010); Echtner and Richie, (2003); Formica and Kothari, (2008) ascribed the competition among tourist destination with 36 attributes basically classified into two. They are the main factor and the sub-main factor. The main factor is made up of five attributes namely 1) Core resources and attraction, 2) Destination management, 3) Qualifying and amplifying determinants, 4) Determinant policy, planning and development and lastly 5) Supporting factors and resources. The sub-main factor is made up of five indicators. They are: 1) Physiology and climate, 2) Combined activities, 3) Culture and history, 4) Tourism superstructure, and 5) Society.

In light of present public interest to develop tourism, it becomes essential and relevant to consider which sites should be selected and accorded priority in tourism development along the river stretch at Asaba and Abraka, as not all sections of the rivers equally qualify for tourism development simultaneously. Crompton, (1997); Craig, (2001); Cohen, (2004); Echner and Ritcher, (2003) and Chatkaewnoponon, (2016) have argued that for effective tourism development, priority must be given to destination sites or regions with higher potentials over others. It has been argued that many tourism projects and programmers in Nigeria suffer from poor patronage and gains because they are not located in the right places due to lack of knowledge of the various destinations through evaluation studies (Omofonmwan, 1999; Chokor, 1993; Baum, (2009); Hall et al., 2008). Tourism site evaluation studies present high advantages for establishing areas of various tourism qualities, which is vital to tourism development in the most appropriately places, and are also important in defining areas that need priority and protection. In spite of such advantages, as in many parts of the developing World, only a few studies have been undertaken to evaluate tourism site preference, patronage and participation patterns in Nigeria.

Additionally, the inclusion of the higher aggregate level determinants provided information on the environment in which various determinants for levels of site destination operation and development. The qualitative investigation into the site selection for the development of tourism within this multi- 
layer system identified reasons and tourism to developed and changed in the study area. While providing a context for different area data analysis, this examination shows that many factors affect tourism development, thereby reinforcing the need for a model that incorporates this complexity. The focus on no preferential data analysis in different areas are patterned on dichotomous evident in data variables, considering the trajectories and change points within each pattern. An important aspect of this approach to understanding tourism site determination was the inclusion of multiple data variables, both tourism specific and general perception of tourist indicators. Analysis of possible relationships between the variables will add greater depth to the study. Testing such a model required the collection of significant data, its analysis, and presentation. Investigation on the research issues, revealed aggregate patterns of the higher level data variables within the array of complex patterns. The study illustrated the need to consider the underlying variables to ensure greater understanding of the complex changes within a destination site. Also important was the inquiry into the remaining research issues to show that there is no single pattern which represents the destination's site. Various patterns exist, such as visitor spending, occupancy levels and the supply of accommodation. The general aim of this study was to further understanding of how and why tourism destinations site will develop. In the future, the knowledge will benefit tourism businesses, associations, managers, and planners. Ultimately, tourism destination planners need to accept that destination site is not a simple and predictable process. Such understanding can then be used to develop a framework for the planning of strategic intervention, which therefore allows for management. This assisted in redirecting tourism site development to ensure that it is economically, environmentally, and culturally sustainable through the facilitation of conducive environment.

\section{Need for the study}

Notably amongst the general tourism studies in Nigeria are those of David, (1998); Archer (1976); Ojo (1983) and Afolabi, (1993). In their majority, these studies have focused on the tourism attitude, destination attractiveness and behavioural patterns of both domestic and foreign visitors and the constraints hindering people's propensity to tourism participation in Nigeria. Sadly, not much work has been done on tourism research to evaluate the environmental potentials of river resources or regions in Nigeria for tourism development; despite the widespread concern for sites selection for tourism development as is the present case of Ethiope River in Abraka, Delta State, Nigeria. It is in the context of such empirical neglect that, this study seeks to evaluate the environmental potentials of various sections or sites of the River Ethiope at Abraka for tourism development.

\section{Aim and objective of study}

This study aims to provide an evaluation of tourism sites along the River Ethiope River, Abraka which could be useful in establishing the relative importance of various sites, and thus aid to identify sites to accord priority in tourism development. The main objective of the study is thus to provide an evaluation of some sites that quality for tourism development along the River Ethiope at Abraka.

\section{Hypothesis}

The null hypotheses proposed are as follow:

The main assumption of the study is that, there are no significant differences between between the environmental qualities of the various sites along River Ethiope at Abraka.

Thus, all sites along the River Ethiope stretch at Abraka are assumed to have similar or equal environmental potentials for tourism development.

\section{Study area}

The study area along River Ethiope at Abraka is located in Ethiope East Local Government Area of Delta State. (Figure 1)

The Abraka section of the River Ethiope occupies the lower section of the upper course of the river, which has its source at Umuaja (23 kms from Abraka) with source from the root of a tree that penetrated the water table. . It is characterised by destination support services natural swift flowing clear water, white sandy streambed, and extensive shallow sandy beaches make up the River Ethiope part of the Abraka section 


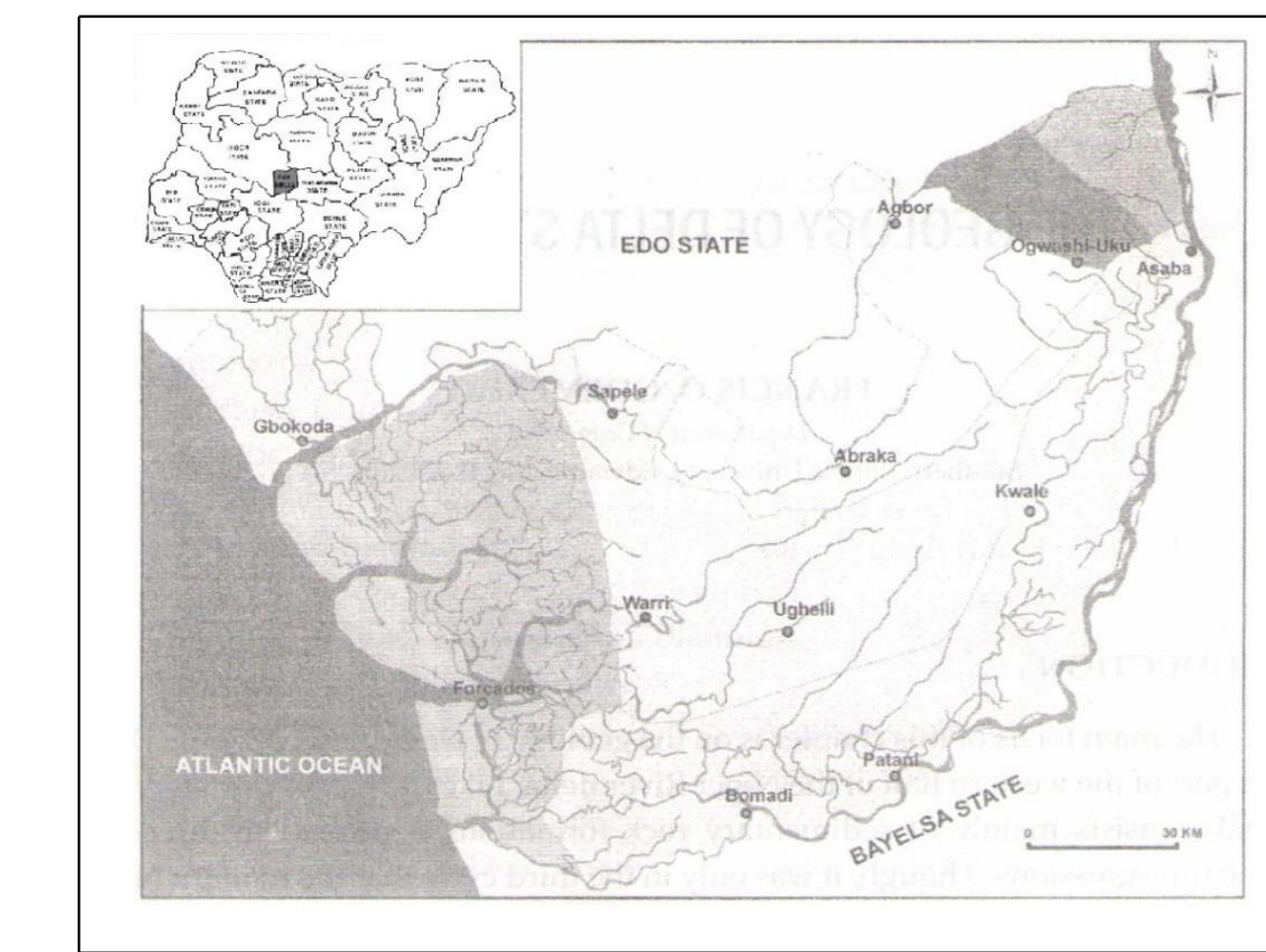

Figure 1: Map of Delta state showing Abraka with Nigeria map incept. Modified from

Nigerian Geological Survey, 2006

Furthermore, in some sections, extensive frontal water landscape, shallow waterfronts and beaches characterize the river, and gentle flowing water current with white sandy beds that are visible common features of the river at Abraka. Several sections of the river are accessible by vehicles and footpaths, and are of varying levels of tourism development. The river flows through dense tropical forest, with wide varieties of animals, birds, insects and plants with climber species adoring and abound in its adjoining river valley. Also, aquatic food varieties of Fishes among others Molluscs are found in adjoining dry but damped leafed ground wetlands areas.

Finally, the selection of five non-professional graduates without previous experiences in tourism too time, money and energy for their training as twenty graduates contacted for their involvement had problem of procedural setback took some time to overcome adoption of five most proficient ones.

\section{Literature review}

Delta State government allocated over N420 million in 2002 and over N800 million in 2019 to Tourism development. The budget is on yearly basis for the development of tourism beaches along River Niger at Asaba and River Ethiope at Abraka. Tourism entertainment column of prominent newspapers like Guardian, Champion and the state-owned Pointer have highlighted the need for development of this section since 2002 to 2020. This put premium on the establishment of ministry for Tourism. The ineptitude of this sector to involve professionals in development of the industry, has put setbacks or governmental to develop with the private sector through supervisory measures. Like most sectors, Nigeria has tourism projects and sectors suffer from poor patronage and gains because they are not located in the right place for Toutris attractiom due to in adequate knowledge of the various destinations through evaluation studies (Omofonmwan, 1999; Chokor, 1993 and Hsu et al, 2007). Like most developing world, few studies were conducted to evaluate tourism site preference in Nigeria and Delta State in particular. Suitably amongst the researchers are David, (1990); Archer, (1976); Ojo (1983); Afolabi, (1993), Baum, (2009), Kotler et al., (2010) and Hall, (2008). Their studies focused on tourist attitude and behaviour pattern of both domestic and foreign visitors and the constraints hindering people's propensity to people participation in Nigeria River Ethiope and its environment presents naturally surrounded tabled landscape and tropical forest vegetation with clear 
water scenery which are highly attractive to the people. However, this study takes advantage of the following;

Baum, (2009) reviewed on Tourism, Destination, attractiveness, attraction and people as predictors examined the influence of Tourist attractions destination support services and people related factors on the attraction of a tourism destination sampled 275 Tourist visit to major tourism destinations. $\mathrm{He}$ used regression model to identify the main contributors to destination attractiveness, the identified core determinants of the attractiveness; destination support facilities and services peoples related factors, though secondary determinants are support facilities and services. The people related factor explained equivalent variances, which suggest complimentary rather than substitutes.

Crompton, (1997); Butler, (2006); and Crai, (2001) have argued for effective tourism development and stated that priority must be given to sites or region with higher potential over others. Baum, (2009) research work on tourism destination attractiveness: attractions, Facilities, and People as Predictors examine the influence of tourist attractions, destination support services, and people related factors on the attractiveness of a tourism destination. A sample survey consisting of 275 tourists visiting the major tourism destinations was conducted and moderated regression of models of study identified main contributors to destination attractiveness. Destination attractions are found to be the core determinants of the attractiveness; destination support facilities and services, and people related factors are the secondary determinants. Support facilities and services and people-related factors explain equivalent variances to suggest that they are complementary rather than substitutes.

Chatkaewnoponon, (2016) writing on understanding a tourist destination using and interactive studies on host communities at different tourist destinations, stated that some studies focus primarily on a particular community to study the implications of tourism development. That many people are interested in a more holistic approach for tourist destination development concepts in various tourist destinations. However, most of those studies limit their attention only to communities during the period of tourism development. There is a lack of theoretical approaches to guide a researcher to develop an understanding of a tourist destination from an integrated, multiple, different timeframe. To this concern, the paper explored the theoretical foundations of a history by drawing on the aspect of tourism history. The tourism history concept in this paper takes a community in their pre-tourism development into the analysis on the community during its meeting through the tourism processes. The understanding of the past will deepen and broaden our understanding of the community's society through a continuous period of its tourism development.

Nyoman and Wayang (2016) investigated the characteristics of domestic tourists that visited Bali, Indonesia had position of competitions among tourist destination and their preference using 12 tourist destinations in the area for which they presented paper in a conference on tourism destination planning strategy: analysis and implementation of marketing city tour in Bali. Bali is one of the tourist destinations in Indonesia and as such, competing against other provinces. It has 113 tourist attractions spreading in 8 regencies and one city in Bali. The study identified 1) the characteristics of domestic tourists visiting Bali 2) the position of competition among 12 tourist destination in Bali and 3) the preference of the domestic tourist to 12 other destination in Bali.

The method of research involved purposeful sampling of 100 people that visited the tourist attractions in Bali. The analyzed data used multiple dimensional scaling. Data were analyzed using descriptive statistical analysis, whose results were chrematistics of respondents who visited the twelfth tourist attractions in Bali, came from 27 cities in Indonesian. The positions of the tourist attractions were grouped into four (4) relative positions; two groups of attractions were positioned to have similarities while the other groups were positioned to be different or less similar. They are highly interested and preferred Sanur and Kuta, followed by Musa Dua and Jimbaran. Zemto (2016) posited that different approaches to analysis or tourism destination for which traditional geographic and economic perspective are presented as the basis for modern system and network approach for which network analysis is noted as the most useful current approach to understand co-operation and competition process taking place in destinations. 


\section{Hypothesis}

The null Hypothesis generated is to establish whether there is significant difference in site evaluation / rankings of environmental qualities between that of the professional's researchers and the five nonprofessionals.

\section{Research methodology}

This research adopts field work for sample collection based on simple random survey method for which reconnaissance field surveys for site selection were conducted along the River Ethiope at Abraka. The study adopts field work, oral interview, field observation and obtaining direct/indirect measurements relating to 40 aesthetic factors in 4 selected sites along the Ethiope River at Abraka. The 40 aesthetic factors on the river sites were selected from previous published works (Leopold, (1969); Odernerho and Chokor, (1993). The 40 items (Table 1) were made up of three major categories, which are physical factors, biologic and water quality factors, and human use and interest factors. Each of the three factors was also further sub-divided in Table 1. Here, Fourteen (14) of the factors were measured under physical factors, thirteen (13) under biologic and water quality factors, while another thirteen (13) were measured under human interest and use factor. Each of the 40 factors was measured using appropriate instruments like measuring tape and floater (for velocity). The use of nominal or interval scales estimated variables, which were not subject to direct measurements in interval scale. Twenty (20) tourism resource sites along the River Ethiope were considered suitable sites for initial evaluation were selected. Three groups of sites emerged from the preliminary survey of those selected: Natural or undeveloped sites, poorly developed sites and well developed sites. And on the basis of simple random process, four sites were finally selected from the three groups of sites for detailed study. Each of the 4 sites was allocated 50 meters stretch in length. Amongst the selected sites, one was selected to represent the undeveloped sites, two sites were selected to represent the poorly or under-developed sites (as these were more common) and one site was selected to represent the developed sites. The locations of these sites are presented in figure $1 \mathrm{~b}$ with their description as follows:

\subsection{Description of selected sites}

The selected sites for this research study are shown on the sketch map (figure 2).

Site 1: Delsu section of the Ethiope River. This is an under-developed or poorly developed site located behind the Ethiope girl's hostel, Campus II, of the Delta State University. It has clear visible water and is surrounded by rainforest vegetation of hardwoods mainly mahogany, Opepe, ironwood, Sapele wood, Matsonia, Iroko, Obeche, dotted with rubber trees in some parts, with proliferations of climbers and impenetrable undergrowth of ferns and grasses. The gradient of the adjoining land is gentle. The river is accessible from the University campus and the students and indigenes of Abraka use it for recreational and domestic purposes. The site was formerly maintained by the University authority and used for recreational activities, but it is no more accessible, maintained and is presently abandoned.

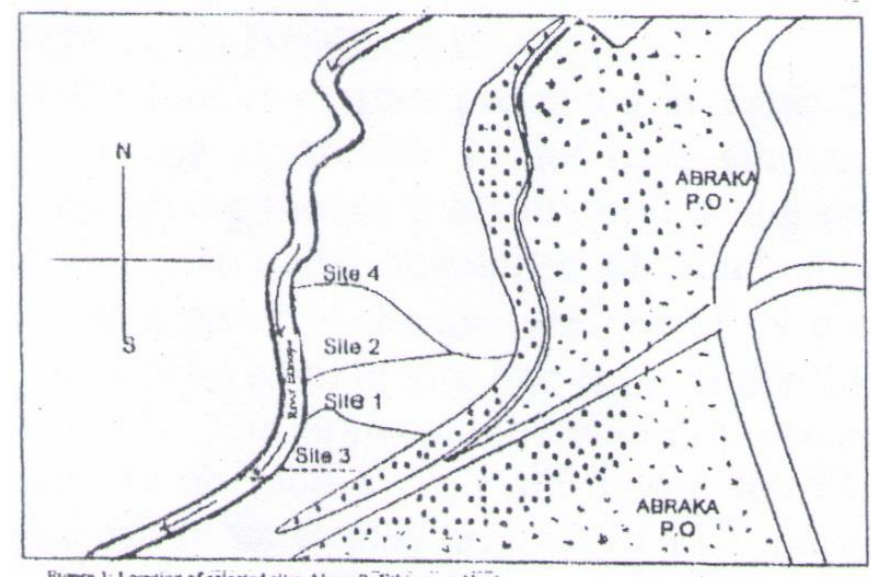




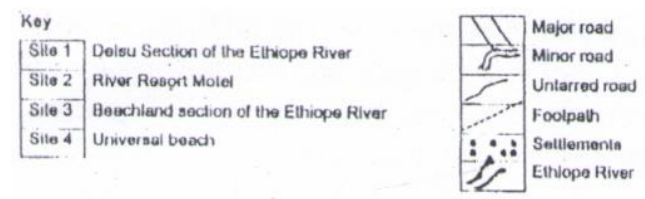

Figure 2: Location sketch of selected sites along River Ethiope at Abraka.

Site 2 - River Ethiope Motel. This is a highly developed section of the River Ehtiope.It is used for recreational and tourist activities. It is Located north of the university campus 2 . It has clear visible water that is surrounded by rainforest vegetation, and it has a vista line of trees and water. The gradient of the adjoining land is gentle and the site is highly accessible from major and minor roads from Abraka.

Site 3 - Beach land section of the River Ethiope . This is an under-developed or poorly developed site that is located south of the River Ethiope at Abraka. The river here is narrow and surrounded by rainforest vegetation. The river view is confirmed and obstructed by surrounding bushes. It is accessible only by footpath. The water is clear and visible.

Site 4- Universal Beach. This is a natural or largely non-developed site that is located north of River Ethiope and north of River Resort Motel. It is surrounded by rainforest vegetation. It has fair vistas of trees and water. The site is highly accessible. It is owed and managed by a private individual. The site is still largely natural as it is at a very low stage of development; and currently used as a recreational centre but has no hotel accommodation.

\subsection{Site evaluation criteria and scale}

The 40 aesthetic factors were measured at each site using the factor scales in Table I (right side columns). Evaluation positions were assigned in Table I (see appendix) in varying degrees to the presence or absence of each factor in a site selected for evaluation. All factors evaluated in each site were assumed to range through a span of five categories, with the quality of a factor increasing as the category number increases. In other words items numbering category five in Table I (see Appendix) were rated as highest quality while category one has lowest quality. In evaluating the four river sites, evaluation scores obtained for each factor at each site was summed up. The results obtained are presented in Table 2 (see Appendix). The addition of the evaluation scores presented in Table 3 (see Appendix) provided a good summary of the physical character of the river sites and also gave reasonable approximations of site desirability. The addition of these evaluation numbers also provided reasonable summaries of the water quality of the river. Thus, the ranking derived from these 40 aesthetic measurements in table 1-3 would be accepted as being reasonable.

\section{Results}

Result of the evaluation of the four river sites presented in Table 2 (see appendix) and THE summary in Table 3 revealed that sites along the River Ethiope at Abraka do not have similar environmental quality to qualify for tourism development, thus nullifying the main assumption of the study.

The study further showed that Site 1, the DELSU section of River Ethiope, an under-developed site, ranked highest in physical and biologic factors and total evaluation. This is as a result of the gentle slope of its riverbank and also the long width of the hank, which measure 22 meters. The bank of site one is far wider than those of sites 2,3 and 4 measuring 16,14, and 17 meters respectively. The slope and the width of a river bank are essential factors which must be considered when planning to develop a river site into a tourist centre, especially for 'the purpose of safety in swimming and also for space to play around. In addition to these two essential qualities of site I mentioned above, the river at DELSU site has the following favourable qualities. It is highly accessible both by foot and vehicles. Its water is visible though deceptively shallow. It has a fairly wide adjoining beach, which is not swampy but firm. The adjoining beach is 32 meters wide. The terrain is smooth, not hilly. Its meander loop is long and wide thereby giving the site a relatively wide space and long sight view. The water condition is good: there is no pollution evidence and it is drinkable. The site has not been affected by 
human interference and has no artificial control. Additionally, Site I is surrounded by natural and well-preserved tropical rainforest vegetation and animals. Studies have shown that natural landscapes, especially those with water scenery, rainforest vegetation and varieties of animal species are highly attractive to people. These attributes of the Delsu section of the river Ethiope at Abraka indicates that the site has very high tourism potential that could be further developed to attract tourists. Site 4 universal beach is a natural and largely undeveloped river site, emerged second highest in total evaluation. It ranked 2 in physical factors, 3 in biologic factors and first in human interest and use. Site 4 has a close similarity in physical factors with site 1 but the difference is in its wider width of river bank and also the more gentle steepness of the bank. The river bank is 17 metres wide; it is wider than those in sites 2 and 3, though shorter than that of site 1 . Unlike site 1, site 4 has a very steep riverbank, which could be dangerous for swimming. Its first position in human interest and use is because the site is less competitive in use unlike sites I and 3 that are highly altered by man. A few people, mostly locals for recreational purposes presently use it. The low patronage is due to its very steep river bank and the fact that the site is located at the outskirts of the town, so the distance from the town reduces the number of patronages especially the domestic users. This is however an advantage over site one.

Site 2- River Resort Motel, a highly developed river site currently used as a tourist and recreational centre, has the 3rd position in total evaluation; it ranked 3rdin physical factors, I in biologic factors and fourth in human interest and use. Unlike site 1, its riverbank is steep and short. Its riverbank is shorter than those of sites 1 and 4, but longer than that of site 3. It ranked first in biologic factor because the management of the motel constantly maintains the river. The number of trashes, cans and litters per every 6 meters is less than 10. This is few compared to that in sites 1,3 and 4 . The only floating materials found on the river site are floating leaves, which is as a result of the tress surrounding the river. These floating leaves could be easily removed. The site has been much altered and affected by urbanization and therefore the site has lost some of its natural originality. Natural recovery is also unlikely in the near future.

Site 3- Beach land section of the River Ethiope is an under-developed or poorly developed site, ranked 4thin total evaluation. It ranked 4thin physical factors, 2 in biologic factors and 3 in human interest and use. Site 3, has the shortest riverbank, which measures 14 meters in width. Its adjoining beach is also the shortest among the 4 sites and it is swampy and rough. Its meander loop is short and narrow, which does not give room for enough space. All these negative factors contributed to the low ranking of site 3 . The only advantage site 3 has over the other 3 sites, is that it has been little affected by urbanization and the site has not also been much altered materially. There are no buildings or any man-made structure in the site, it is therefore in its natural state and this gives the site a natural attractiveness. Another disadvantage site 3 has is that it is not been very accessible. The only accessible route to the river site is a footpath. This implies that vehicles do not have direct access to the river bank because of its difficult terrain and sometimes flooded adjoining beach area.

\subsection{Reliability tests}

It is considered important to further establish the reliability of the outcome of the site evaluation. Accordingly, a team of 5 graduate students from the Faculty of Arts/Social Sciences, Delta State University Abraka were selected to re-evaluate the four river sites, using the 40 landscape evaluation factors in Table 3 (see appendix). It was to ensure that the 5 selected students have no previous training in landscape evaluation. It was however considered important that the 5 students had previous tourism / travel experiences to various tourism destinations in Nigeria within the past three years.

These groups of 5 persons were therefore considered as previous tourist or non-professional assessors. The result of the re-evaluation process by the 5 previous tourist subjects or non-professional assessors is presented in Table 4 (see appendix) and also summarized in Table 005.

The result of the sites evaluation carried out by the 5 non-professionals showed that site I (Delta State University site) ranked highest in total evaluation and was regarded thus as the most suitable site for development of river tourism along the River Ethiope at Abraka. This result corresponds with the 
result earlier obtained by the researchers. This goes to confirm the high tourism potential of the Delta State University (Delsu) section of the River Ethiope at Abraka.

The assessment also revealed that site 2 River resort motel, has the second highest number in total evaluation by the non-professional assessors as a result of the level of development which they scored very high compared to that in other sites. This result did not however correspond with the initial research result. In fact, site 2 is ranked 3 rd in the total evaluation from first episode.

This difference in position may be attributed to the fact that while level of site developed did not emerged as a major criterion in the first assessment of the river sites by the main researchers, who are professionals, it appeared as most important in the second evaluation by the 5 non-professional evaluators. In contrast, more emphasis was laid on the human, features and level of site development by the non-professionals, while the first evaluation by the professional researchers emphasized natural physical and biological factors as of more importance in landscape evaluation for leisure visitors or tourists. Universal beach and the Beach land sections of the Ethiope River ranked 3 and 4thpositions respectively in total evaluation by the non-professional assessors. In human interest and use, Beach land (site 3 ) ranked second to the highest.

\subsection{Hypothesis testing of site evaluation using Student t test}

Student $t$ test is a parametric statistical technique for independent samples generated. This flexible statistical tool is useful in the analysis of two or more sample situation that enable the researcher to establish by testing (if any) differences existing between variables in a population of data generated. It therefore tests for difference (if any between 2 sample data set measured from interval scale drawn from normal distributed population and the two data set are random sample from a normally or near normal population distribution (Awaritefe, 2008). For this research analysis, a record of measurement for randomly selected Tourist (Professionals and non-professionals). The difference will be accurately reflected in the samples at 0.05 level of significance decided upon by the equation.

$\mathrm{t}=$

$$
\sqrt{\frac{(\bar{X}-\bar{Y})}{\sum^{2}\left(n-x^{2}-y^{2}-\sum n^{2}(n y)-y^{2}\right.} \frac{n y-1}{n x-1}}
$$

Thus, $\mathrm{t}=$

difference between the mean

Standard error of the difference

The computer programming for the $t$ test parametric statistical method is carried out to determine the relationship of the variables (if any the evaluations of the two groups of professional and nonprofessional assessors. The programmed result for the data generated (Table 4) for testing as follows;

\subsection{Hypothesis testing}

The student $t$ test was undertaken to compare the evaluations of the two groups of professional and non-professional assessors. With a calculated value of 0.143 and T-table value of 0.283 , with df2:3 at 0.0 level of significance, the difference in site ranking between the first and second evaluation was therefore, not considered significant. High confidence or reliability can therefore be placed on the tourism site evaluation results obtained at the 0.05 significance level.

\section{Conclusion}

The study evaluated the tourism potentials of four sites randomly selected along the River Ethiope at Abraka. The study measured a set of 40 physical, biological and human factors in each of the four sites, using a five point bi polar scale. The four river sites selected for detailed study were: 1 . Delta State University (Delsu) section of the Ethiope River, 2. River Resort Motel Section 3. Beach land section and 4, Universal beach section. Result of the study confirmed that the various sites along the Ethiope River at Abraka possess different environmental qualities. Priorities was accorded to some sites in tourism development of the area revealed that the Delta State University section of the River Ethiope has the highest tourism potential. Universal beach section ranked 2", followed by the River Resort Motel (3). The beach land section emerged 4th position. It has the lowest total evaluation 
scores. Based on the findings of the study, it is suggested that highest priority should be accorded to the development of the Delta State University section of the Ethiope River. Next, priority should be given to the Universal beach section, followed by the Motel, which is also well developed. The study showed that the DELSU and universal beach sections, like many other similar under-developed and non-undeveloped (natural) sites, have high potentials for tourism, which if developed could attract tourists from all over the country/internationally and generate high tourism benefits to the state and private investors. However, because the most favoured site is located inside the Delta State University campus, it is specifically suggested that the university authority and indeed Delta State University should invest in the development of the site as a commercial tourism venture. This would boost leisure attitudes among students and lecturers, attract tourists from all over the country, and also raise revenue for the University. The study also suggest that while tourism site evaluation by professional researchers may be highly reliable, such studies may also tend to either over-emphasize or deemphasize certain factors, or such studies may even be over-critical in assessing certain factors of the environment (Chokor, 1990; Baum, (2009). For instance, in this study, the researchers as professionals, appeared to emphasize natural factors, while the 5 non-professionals of the 10 students (without previous knowledge on tourism), tended to emphasize some level of site development based on human factor (Table 4) (see Appendix). Such differences in perspectives between the professional assessors (the researchers) and non-professionals (users as tourists) as reflected in this study, calls for a merger in perspectives between professionals and non-professionals (tourists) in tourism site evaluation in order to obtain more balanced and comprehensive results or picture in tourism site or destination development programmes.

\section{Limitations of study}

The area lies within tropical equatorial rain forest vegetation which is an impenetrable ticket of under growth with trees and climbers. Moreover, dangerous reptiles especially (snakes and crocodile) as well as insect (Mosquitos and tsetse fly) are present and harmful to man in the environment. Furthermore, the sinking muddy surfaces in some areas as well as the land slopping towards the rivers constitute harsh environment during field observation and research work at the various site.

\section{Implication of study (site selection process)}

The proposed model of site election is useful for heterogeneous vegetative setting together with natural existence. The thyroids of equatorial rainfall vegetation display natural luxuriant spaces of hard wood with under-growths, climbers of numerous species with reptiles and animals abound. However, natural activities of drought due to climate change effects promoted by bush burning, grazing and farming land (anthropogenic) activities result secondary growth within the natural settings. Thus, there need for clarification of natural and artificial vegetation settings in the site selection process.

\section{References}

Afolabi, F. (1993). The relative importance of environmental beautification and other factors in domestic patronage of tourists centres and attractions in Ado Ekiti, Ondo State. A B.A. submitted to Ondo State University Akure, 107p

Archer, B. (1976). Tourism in the third world: some economic considerations, inaugural lectures, Guild Ford. Surrey University.

Awaritefe, D. (1997. Recreational space facility provision in Nigeria cities: the case of' Benin City. A Paper presented at Nigerian Geographical Association Conference, Zaria, 21p.

Baum,T. (2009). Tourism destination attractiveness: attractions, facilities and people as predictors article in tourism analysis. Source https://www.researchgate.net/publication/233643032. Doi103727/108354209x12597959359211.

Butler, R.W. (2006). The tourism area life cycle: applications and modifications. Clevedon: Cromwell Press, 58p.

Chatkaewnoponon, P. (2016). Understanding a tourist destination: a tourism history. The Czech Academy of Science Journal. Moravian Geographical Report 24 (4), 2-14.

Chokor, B. (1990). Environment - behaviour - design research: an agenda for the third world. Environment and Planning, 20, 425-434. 
Chokor, B. (1993), Perspectives on environment and tourism in Nigeria, in B. Chokor (Cd) environment and tourism in Nigeria. Lagos: Environment and Behaviour Association of Nigeria, 1-12.

Chokor, B. (2009). Environment and tourism in Nigeria, Lagos. Environment and Behaviour Association of Nigeria, 125-145.

Cohen, E. (2004). Contemporary tourism: diversity and change. Amsterdam: ELSEVIER

Cooper, F.; Gilbert, O. \& Wanhill, P. (1993). Tourism Principles \& Practice. Pitman Publishing, $54 \mathrm{p}$.

Craig, S. (2001). Land use component approach to landscape evaluation, Institute of British Geographers Transactions no. 66.

Crompton, J. (1997), An assessment of the image of Mexico as a vacation destination and the influence of geographical location upon that image. Journal of Travel Research 1, 17(4), 18-24.

David, H. (1998). Geography and the geography teacher, London: George Allen and Unwin Publishers Ltd. Desai, A. (1986), The environmental perception of an urban landscape: the case of Ahmedahad. Ekistics, 283, 279-285.

Echtner, M \& Ritchie J. R. (2003). The meaning and measurement of destination image. The Journal of Tourism Studies. 17, 1, 37-48

Formica, S. \& Kothari, T. H. (2008). Strategic destination planning: Analyzing the future of tourism. Journal of Travel Research, 46(4), 355-367.

Govers, R., Go, F.M \&. Kumar, K. (2007). Promoting tourism destination image. Journal of Travel research, 46(1), 15-23.

Hall, C. M. (2008). Tourism planning: policies, processes and relationships. England: Pearson Prentice Hall, 126p.

Hsu, K., Killion, L.; Brown, G.; Gross, M. \& Huang, J. (2008). Tourism marketing: an Asia Pacific perspective. Australia: John Wiley, 94p.

Kotler, K. (2009). Manajemen Pemesaran. edisi 13 jilid 1. (Bob Sabran, Penterj). Jakarta: Erlangga, $12 \mathrm{p}$.

Kotler, P, ; Bowen, J.; Makens,T. \& James C.(201 0). Marketing for hospitality and tourism (fifth edition). New Jersey: Pearson. Prentice Hall, 50p.

Kotler, P. (2000). Management pemasaran (Edisi Milenium). Jakarta: Pearson Education dan Prehanllindo, $17 \mathrm{p}$.

Leopold, L. (1961). Quantitative comparison of some aesthetic factors among rivers. Circular 620 of the United States Geological Survey, Washington, D.C, $1-31$.

Mill, M. A . (2009). The tourism system, sixth edition. USA: Kendall Hunt, 30p

Nyoman, S. \& Wayan, S. (2016). Tourism destination planning strategies: analysis and implementation of marketing city tour in Bali Indonesia. A Paper Presented in International Conference: Intelligent Planning Towards Smart City on 3rd November, 2015, Surabaya, Indonesia.

Odemerho, F. \& Chokor, A. (1963), An aggregate index of environmental quality: the example of a traditional city in Nigeria. Applied Geography, 11, 35-58.

Ojo, G. (1983). Recreation and tourism in Nigeria: patterns and trends. Oguntoyinbo, J. Areola, S.O. And Filani, N. (eds.) A Geography of Nigerian Development Ibadan: Heinemann Books, 24'45

Omofonmwan S. (1990). Landscape evaluation of tourism development. a paper presented at the $33 r d$ annual conference of Nigerian Geographical Association, held at University of Benin, Benin City. In Adejuyibe, 0. and Helleina, F. (eds) University of ife, $143-150$.

Ritchie, J. R, \& Crouch, G. I. (2010). A model of destination competitiveness/sustainability: Brazilian perspectives. Revista de Administracao Publica, 4(1) 1049-66.

UNWTO, (2012). World tourism barometer. 10(2) January, no 2012.

Zemto, M. (2016) Tourism destination: the network approach. a paper presented to department of tourism and referral studies, Institute of Geography/. Pedagogical University, Cracow, Poland,s 87-98. 


\section{APPENDICES}

TABLE. 1: 40 Fvaluated Aesthetic Factors at Selected Sites of River Ethiope, Abraka.

\begin{tabular}{|c|c|c|c|c|c|c|}
\hline \multicolumn{4}{|c|}{ Evalueting Seale of the 40 Calegaries of liteme } & \multicolumn{3}{|c|}{5 point scale } \\
\hline $\begin{array}{l}\text { Iaci } \\
\text { in } \\
\text { No }\end{array}$ & Phrvisal Facton & 1 & 2 & 3 & 4 & 5 \\
\hline 1 & Kiret & $<15 \mathrm{~m}$ & $15 \mathrm{~m}$ & $27 \mathrm{~m}$ & $40 \mathrm{~m}$ & $70 \mathrm{~m}$ \\
\hline 2 & Depth of twer in metres & $<7 m$ & 6in & $\sin$ & $4 m$ & $3 m^{-}$ \\
\hline 3 & Velocity: metrelsecond & 03 & 0.2 & 0.1 & 0.01 & .001 \\
\hline 4 & Flow variability & Targe & 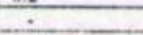 & Intile & 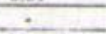 & Normal \\
\hline 3 & Rive Iallern & Timient & $\begin{array}{l}\text { Pool and } \\
\text { rifle }\end{array}$ & ilinaded & Meander & Killes \\
\hline 6 & lled muterial & Clay of sili & Cobhiles & $\begin{array}{l}\text { Misture of and } \\
\text { and gravel }\end{array}$ & Gravel & Sand \\
\hline 7 & Slope of rwee hank & Steep & - & - & - & Gentie \\
\hline 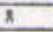 & Width of nver tanks in metrs & $<10 \mathrm{~m}$ & $14 \mathrm{~m}$ & $16 \mathrm{~m}$ & $17 \mathrm{~m}$ & $22 \mathrm{~m}$ \\
\hline 9 & Width of adjoining beach in metres & $<10 \mathrm{~m}$ & $20 \mathrm{~m}$ & $32 \mathrm{~m}$ & $39 \mathrm{~m}$ & $40 \mathrm{~m}$ \\
\hline 10 & Nalure of ternin & Rugged & $\therefore$ & $\dot{-}$ & $\cdot$ & Smooth \\
\hline II & Firmness of adjoining heach & Swampy & - & - & 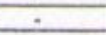 & Firm \\
\hline 12 & Frosion of thenk & Eroding & $\div$ & Slumping & $\div$ & Sinble \\
\hline 13 & Deposition & Stable & $\div$ & 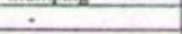 & 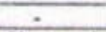 & large \\
\hline 14 & Sine of meander loop & Shon \& narrow & Long \& narrow & $\cdot$ & $\begin{array}{l}\text { Short and } \\
\text { wide }\end{array}$ & 1. ong \& wide \\
\hline 15 & $\begin{array}{l}\text { Biologic A wnier Guality Festen } \\
\text { Water colour }\end{array}$ & Brown & Clay & Muddy & Green & Claet \\
\hline 16 & Turbidity & Large & 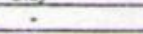 & Medium & - & Small \\
\hline 17 & Floeting materials & Varicty & Oily & Foemy & $\begin{array}{l}\text { Vegetatio } \\
\text { n }\end{array}$ & None \\
\hline 18 & Trnsh \& litternos $6 \mathrm{~m}$ & 325 & 25 & 20 & 15 & -10 \\
\hline 19 & Mtaicriais remonahle & Diflicull & $\therefore$ & 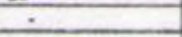 & $\therefore$ & Fasily removed \\
\hline 20 & Pollution evidence & Evident & 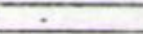 & 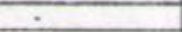 & - & None \\
\hline 21 & Woter visibality & Poor & $\div$ & Good & $\div$ & Excellent \\
\hline 22 & Water visibility & Not visible & $\cdot$ & $\cdot$ & $\cdot$ & $\begin{array}{l}\text { Visible river } \\
\text { hed }\end{array}$ \\
\hline 23 & Landflora Amount & Aberent & - & Few & 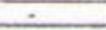 & Inicsted \\
\hline 34 & Landfor & Cinss & $\div$ & Minture & - & Trees \\
\hline 25 & Tandforr Condition & Poot & $\div$ & Cimsus ktrees & - & Absent \\
\hline $2 \pi$ & Algae Tyrs & Inievad & $\div$ & tew & $\div$ & Abseni \\
\hline 27 & Algae Type & $\begin{array}{l}\text { Gircen } \\
\text { woods }\end{array}$ & Blue Green & Diatom & Weeds & None \\
\hline $2 \pi$ & $\begin{array}{l}\text { Illamas laterest and lise Factors } \\
\text { Anificial control (dams dykes. } \\
\text { dredging) }\end{array}$ & Controlled & - & - & - & Free and natural \\
\hline 29 & Accessibility & Not accessible & $\cdot$ & Accessible by foot & - & $\begin{array}{l}\text { llighly } \\
\text { accessible }\end{array}$ \\
\hline 30 & Local scene, diversity & No divervily & $\div$ & - & $\cdot$ & Diverse Views \\
\hline 31 & Virtas & Nonvitas & $\therefore$ & 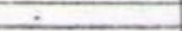 & $\because$ & Iar visto \\
\hline 32 & View conflinement & Cloeed & $\overline{-}$ & $\div$ & $\div$ & Open \\
\hline 33 & Land use & Fishing & Village shine & Girscing & $\begin{array}{l}\text { Fishing \& } \\
\text { recreation }\end{array}$ & Recrcation only \\
\hline 34 & Landuse (competition) & $\begin{array}{l}\text { Highly } \\
\text { conipetilive }\end{array}$ & . & Less competitive & - & Not competitive \\
\hline 35 & Urilitics, Otwetruction of Yicw & Onstructed & $\div$ & $\overline{-}$ & $\overline{-}$ & Unobsincted \\
\hline 16 & 1xegree of chanze & Much allered & 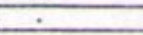 & Slighily altered & $\dot{\square}$ & Original \\
\hline 37 & Kecovery potential & Unlikely & 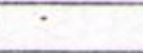 & . & . & $\begin{array}{l}\text { Natural } \\
\text { recovery }\end{array}$ \\
\hline 38 & Uttenization & Many buildings & $\cdot$ & Few buildings & $\begin{array}{l}\text { One } \\
\text { building }\end{array}$ & No building \\
\hline 39 & Special vieues & None & $\cdot$ & 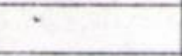 & $\cdot$ & $\begin{array}{l}\text { Dinusual } \\
\text { interes }\end{array}$ \\
\hline 40 & $\begin{array}{l}\text { Misfits (Sharp rock, dangerous } \\
\text { animals) }\end{array}$ & Many & - & Few & $\cdot$ & None \\
\hline
\end{tabular}




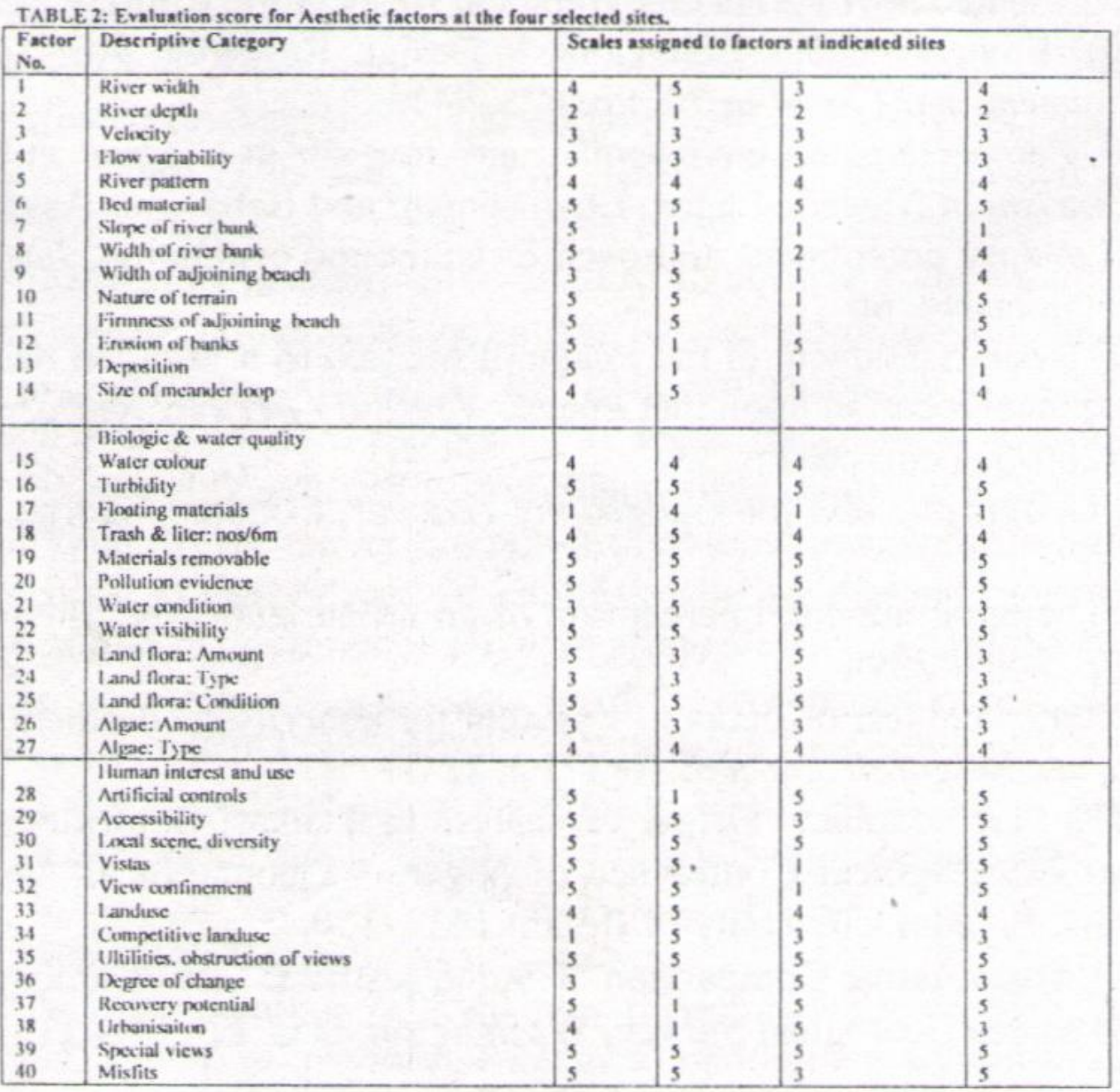

TAB1,E 3: Summary of evaluation scores for aesthetic factors at selected sites

\begin{tabular}{|l|l|l|l|l|l|}
\hline & & Aesthetic factors & & \\
\hline & & Physical & Biologic & Iluman & Total \\
\hline 1. & Delsu section & 58 & 52 & 57 & 167 \\
\hline 2. & River Resort Secion & 47 & 56 & 49 & 152 \\
\hline 3. & Beachland section & 33 & 52 & 50 & 135 \\
\hline 4. & Universal beach & 50 & 50 & 58 & 158 \\
\hline & Total & 188 & 210 & 214 & 612 \\
\hline
\end{tabular}




\begin{tabular}{|c|c|c|c|c|c|}
\hline \multirow{2}{*}{$\begin{array}{l}\text { Factor } \\
\text { No. }\end{array}$} & \multirow{2}{*}{$\begin{array}{l}\text { Descriptive category } \\
\text { Physical factors } \\
\end{array}$} & \multicolumn{4}{|c|}{ Category assigned to factors at indicated sites } \\
\hline & & 1 & 2 & 3 & 4 \\
\hline 1 & River width & 0 & 25 & 15 & 20 \\
\hline 2 & River depth & 10 & 7 & 11 & 10 \\
\hline 3 & Velocity & 17 & 15 & 15 & 15 \\
\hline 4 & Flow variahility & 14 & 15 & 15 & 15 \\
\hline 5 & River pattern & 21 & 20 & 20 & 20 \\
\hline 6 & I3ed material & 25 & 25 & 25 & 25 \\
\hline 7 & Slope of river bank & 25 & 5 & 9 & 17 \\
\hline 8 & Width of river bank & 23 & 17 & 9 & 18 \\
\hline 9 & Width of adjoining beach & 18 & 25 & 5 & 20 \\
\hline 10 & Nature of terrain & 25 & 24 & 5 & 24 \\
\hline 11 & Firmness of adjoining beach & 21 & 21 & 5 & 20 \\
\hline 12 & Erosion of banks & 21 & 5 & 20 & 21 \\
\hline 13 & Deposition & 20 & 9 & 5 & 8 \\
\hline \multirow[t]{2}{*}{14} & Size of meander loop & 16 & 24 & 8 & 19 \\
\hline & Total & 276 & 237 & 167 & 252 \\
\hline 15 & $\begin{array}{l}\text { Biologic \& water quality } \\
\text { Water colour }\end{array}$ & 19 & 20) & 20) & 19 \\
\hline 16 & Turhidity & 24 & 24 & 25 & 25 \\
\hline 17 & 1\%loating materials & 7 & 8 & 8 & 8 \\
\hline 18 & Trash \& liter: nos/6m & 13 & 24 & 11 & 14 \\
\hline 19 & Materials removable & 24 & 25 & 25 & 25 \\
\hline 20 & Pollution evidence & 25 & 25 & 25 & 25 \\
\hline 21 & Water condition & 17 & 24 & 17 & 17 \\
\hline 22 & Water visibility & 23 & 21 & 21 & 22 \\
\hline 23 & Land flora: Amount & 24 & 17 & 23 & 17 \\
\hline 24 & Land flora: Type & 19 & 17 & 19 & 17 \\
\hline 25 & I and flora: Condition & 2.3 & 23 & 2.3 & 23 \\
\hline 26 & Algac: $A$ mount & 17 & 17 & 17 & 17 \\
\hline \multirow[t]{2}{*}{27} & Alpac: Type & 19 & 20 & 17 & 19 \\
\hline & Total & 254 & 265 & 251 & 248 \\
\hline & Iluman interest and use & & & & \\
\hline 28 & Artificial controls & 13 & 5 & 25 & 17 \\
\hline 29 & Accessibility & 24 & 24 & 15 & 25 \\
\hline 30. & local secne, diversity & 21 & 25 & 21 & 21 \\
\hline 31 & Vistas & 17 & 25 & 5. & 21 \\
\hline 32 & View confinement & 16 & 25 & 5 & 21 \\
\hline 33 & Landuse & 21 & 25 & 20 & 19 \\
\hline 34 & Competitive landuse & 9 & 25 & 15 & 16 \\
\hline 35 & Utilities, obstruction of views & 25 & 25 & 23 & 23 \\
\hline 36 & Degree of change & 15 & 9 & 25 & 17 \\
\hline 37 & Recovery potential & 21 & 5 & 25 & 17 \\
\hline 38 & Urbanization & 20 & 5 & 25 & 17 \\
\hline 39 & Special views & 24 & 21 & 25 & 23 \\
\hline \multirow[t]{2}{*}{40} & Misfits & 20 & 22 & 16 & 19 \\
\hline & Total & 246 & 241 & 245 & 239 \\
\hline
\end{tabular}

TABLE 5: Summary score for Aesthetic factors of four sites evaluated by five non-professionals.

\begin{tabular}{|c|c|c|c|c|c|}
\hline \multirow[b]{2}{*}{$\begin{array}{l}\text { Site } \\
\text { No. }\end{array}$} & \multirow[b]{2}{*}{ River sites } & \multicolumn{4}{|c|}{ Aesthetic factors } \\
\hline & & Physical & Biologic & lluman & Total \\
\hline 1 & Delsu & 278 & 254 & 246 & 778 \\
\hline 2 & River Resort Motel & 237 & 265 & 241 & 743 \\
\hline 3 & Beachland & 167 & 251 & 245 & 663 \\
\hline 4 & Universal beach & 252 & 248 & 239 & 739 \\
\hline 3 & Total & 934 & 1018 & 971 & 2923 \\
\hline
\end{tabular}

